\title{
Intervenção de arquitetura para uma escola Guarani: processo de projeto e apropriação de ambientes educativos na Tekoa Itaty, SC
}

\author{
Architecture Intervention for a Guarani school: project process and \\ appropriation of education environments at Tekoa Itaty, SC \\ Intervención de arquitectura para una escuela Guaraní: proceso de proyecto y \\ apropiación de ambientes educativos en Tekoa Itaty, SC
}

\author{
Nauíra Zanardo Zanin ${ }^{1}$ \\ Alicia Norma González de Castells ${ }^{2}$
}

Recebido em: 12/07/2018;revisado e aprovado em: 27/05/2019;aceito em: 19/06/2019 DOI: http://dx.doi.org/10.20435/inter.v21i3.2074

\begin{abstract}
Resumo: Neste artigo, refletimos sobre intervenções arquitetônicas realizadas em comunidades indígenas e as consequentes alterações que podem surgir na organização socioespacial dos assentamentos. Analisamos a intervenção arquitetônica realizada para a Escola Itaty (Palhoça, SC) e as transformações espaciais desencadeadas na ocupação do território, identificando, ainda, como os modos próprios de educar dos Guarani revelam a apropriação pela comunidade e a expansão da educação escolar para outros lugares de aprendizagem. Como procedimentos metodológicos, recorremos a estratégias do método etnográfico, realizando observações, interlocuções, grupos focais, registro fotográfico, levantamento documental, entre outros, e embasando as análises em referenciais teóricos multidisciplinares.
\end{abstract}

Palavras-chave: arquitetura e urbanismo; educação escolar indígena; ambientes escolares; lugares de aprendizagem; Guarani.

Abstract: This article brings reflection upon architectural interventions performed in indigenous communities and the subsequent alterations that may occur in the settlements' socio-spatial organization. We analyzed the architectural intervention performed for the Itaty School (Palhoça, SC) and the space transformations initiated on the occupation of the territory, also identifying how the Guarani's own ways of education reveal the appropriation by the community and the spreading of school education to other places of learning. As methodological procedures, we used strategies of the ethnographic method, making observations, interlocutions, focus groups, photographic record, documentary survey, among others, and supporting the analyzes in multidisciplinary theoretical references.

Keywords: architecture and urbanism; indigenous school education; school environments; places of learning; Guarani.

Resumen: En este artículo, reflexionamos sobre intervenciones arquitectónicas realizadas en comunidades indígenas y las consecuentes alteraciones que pueden surgir en la organización socioespacial de los asentamientos. Analizamos la intervención arquitectónica realizada para la Escuela Itaty (Palhoça, SC) y las transformaciones espaciales desencadenadas en la ocupación del territorio, identificando asimismo como los modos propios de educar de los Guaraní revelan la apropiación por la comunidad y la expansión de la educación escolar para otros lugares de aprendizaje. Como procedimientos metodológicos, recurrimos a estrategias del método etnográfico, realizando observaciones, interlocuciones, grupos focales, registro fotográfico, levantamiento documental, entre otros, y basándose en los análisis en referencias teóricas multidisciplinarias.

Palabras clave: arquitectura y urbanismo; educación escolar indígena; ambientes escolares; lugares de aprendizaje; Guaraní.

\section{INTRODUÇÃO}

O presente artigo apresenta reflexões sobre intervenções de arquitetura realizadas junto a povos indígenas, por meio do estudo de caso de uma escola Guarani. Para tanto, apresentamos

\footnotetext{
${ }^{1}$ Universidade Federal da Fronteira Sul (UFFS), Erechim, Rio Grande do Sul, Brasil.

${ }^{2}$ Universidade Federal de Santa Catarina (UFSC), Florianópolis, Santa Catarina, Brasil.
} 
inicialmente alguns aportes teóricos que orientaram nosso olhar para a análise do caso, possibilitando a compreensão de que os ambientes escolares não estão necessariamente restritos à arquitetura escolar, mas podem se expandir para o contexto da comunidade indígena na qual a escola está inserida. Outros lugares podem ser caracterizados como lugares de aprendizagem, integrando atividades escolares às atividades cotidianas da aldeia. Dessa forma, as crianças e os jovens indígenas podem dar continuidade ao aprendizado pela experiência (BONDÍA, 2002), vivenciando lugares significativos do entorno, os quais fazem parte do território e da paisagem em que vivem (INGOLD, 2010, 2015).

Entretanto esse tipo específico de educação escolar, que respeita os modos próprios de educar de cada povo, embora reconhecido pela Constituição Federal de 1988 (CF-88), não acontece em todas as comunidades indígenas. O histórico da educação escolar indígena é marcado pela assimilação das culturas nativas com a intenção de "civilizar" esses povos. Atualmente, a legislação respalda a utilização de línguas maternas e processos próprios de aprendizagem, indicando, inclusive, a participação da comunidade na definição da arquitetura que abrigará a escola (BRASIL, 1999, 2012). Contudo, em muitas aldeias, a "cultura escolar" (FARIA FILHO, 1998) permanece como o modelo a ser seguido com relação ao uso dos espaços e dos tempos de aprendizado.

Apresentaremos, neste artigo, resultados do estudo de caso sobre a intervenção arquitetônica para a Escola Indígena de Ensino Fundamental Itaty (Escola Itaty), localizada na Tekoa Itaty, em Palhoça, Santa Catarina. O objetivo principal da pesquisa ${ }^{3}$ foi analisar a intervenção arquitetônica da Escola Itaty e os reflexos na apropriação e no uso de ambientes escolares na Terra Indígena (TI) Morro dos Cavalos. Essa escola foi construída em decorrência dos direitos conquistados pelos povos indígenas a partir da CF-88. Durante a pesquisa, procuramos conhecer o histórico de implantação, o processo de projeto e a apropriação da escola pela comunidade. Constatamos, dessa forma, algumas transformações decorrentes da intervenção de arquitetura para a construção dessa escola e seu impacto na organização espacial da aldeia. São apresentados dados obtidos em interlocuções, observações, grupos focais, documentos e referencial teórico.

Como resultados, apresentamos reflexões e interpretações sobre a intervenção arquitetônica para a Escola Itaty e as alterações desencadeadas na ocupação espacial. Apresentamos, ainda, a apropriação da escola pela comunidade e o uso de lugares de aprendizagem que se estendem a outros ambientes. Observamos que a arquitetura escolar pode se tornar o centro da comunidade, abrigando muitas atividades, e não somente as escolares. As atividades escolares, por sua vez, não se restringem ao espaço físico delimitado para a escola, mas expandem-se para outros lugares de aprendizagem, entrelaçando a comunidade e seu entorno em ambientes que revelam memórias e, com elas, a história de ocupação do território. Esperamos trazer contribuições para futuras intervenções arquitetônicas e urbanísticas em comunidades indígenas no Brasil, bem como para o planejamento conjunto de espaços escolares indígenas.

\footnotetext{
${ }^{3}$ Este artigo é derivado de tese de doutorado intitulada Intervenções arquitetônicas junto a povos indígenas: processo de projeto, apropriação e uso de ambientes escolares, de autoria de Nauíra Zanardo Zanin (2018), desenvolvida no PósARQ/UFSC, sob orientação de Alicia Norma Gonzáles de Castells.
} 


\section{PROCEDIMENTOS METODOLÓGICOS}

A pesquisa desenvolvida teve uma abordagem qualitativa, contemplando: contato direto com o ambiente estudado, em um trabalho intensivo de campo, a fim de conhecer o contexto; coleta e produção de dados que possibilitassem a descrição do problema; preocupação maior com o processo de pesquisa do que com o produto; tentativa de captar as perspectivas dos participantes, em busca de significados por eles atribuídos; análise dos dados, que partiu de questões amplas, delimitadas no aprofundamento do estudo e com base nos referenciais teóricos (LÜDKE; ANDRÉ, 2012).

Foram utilizadas estratégias do procedimento etnográfico, como a observação participante, a entrevista em profundidade, diálogos com grupos focais e análise documental, por possibilitarem maior eficiência na obtenção de dados (ANDRÉ, 2012). Foram observadas atividades realizadas nos espaços escolares ou educativos de comunidades indígenas, o que, segundo Gifford (1997), pode ser um guia mais adequado que as informações obtidas por meio de entrevistas. As observações ocorreram durante as interlocuções e a realização de atividades escolares, mas também com a escola vazia, quando foram registrados vestígios comportamentais (ELALI, 1997; GUNTHER; ELALI; PINHEIRO, 2004).

Nas observações, um importante recurso foi o registro fotográfico. Lucrécia Ferrara (1997) instiga o aguçamento da percepção espacial a partir de registros fotográficos, que não captam apenas um instante, mas a perspectiva de quem observa - o que sugere interpretações e revela a força vital de um lugar. O registro fotográfico de um instante pode ser enriquecedor para a análise posterior, quando a memória já não está tão acurada e as anotações de campo não alcançam todos os detalhes (ATTANÉ; LANGEWIESCHE, 2005).

Roberto Cardoso de Oliveira (1998) defende a qualificação dos dados obtidos por meio da observação participante e interlocução dialógica, por permitirem uma aproximação maior com a visão de mundo do interlocutor. Richardson (1985) se refere às entrevistas não estruturadas como entrevistas em profundidade, por buscar do entrevistado os dados considerados por ele como mais relevantes. Para o registro das interlocuções com indígenas, foram utilizados a caderneta de anotações e o diário de campo. As entrevistas com não indígenas também foram gravadas e transcritas.

Foram realizados diálogos com grupos focais compostos por integrantes da comunidade indígena escolhida para o estudo, considerando a representatividade social e a relação desses sujeitos com o objeto da discussão (GONDIM, 2003; MINAYO, 2015). Para o desenvolvimento dos grupos focais, foram utilizadas estratégias de pesquisa voltadas à investigação das relações pessoa-ambiente (ELALI, 1997; GUNTHER; ELALI; PINHEIRO, 2004), como a utilização de imagens para análise e/ou seleção, confecção de mapas (individuais e coletivos), desenhos, entre outros.

O grupo focal foi realizado com professores Guarani, para identificarem os lugares de aprendizagem utilizados nas atividades escolares. Foram registradas as informações sobre os caminhos e as trilhas, a vegetação, as pessoas, o uso dos espaços e sua relação com as atividades escolares e a conexão entre eles. Os professores também contaram histórias sobre a ocupação da aldeia e desenharam mapas contando como era utilizado o território pelas famílias antes e depois da construção da escola. Essa atividade permitiu identificar como as intervenções arquitetônicas e de infraestrutura alteraram a ocupação e organização espacial das famílias. Também possibilitou conhecer de que forma ocorreu a apropriação da comunidade com relação aos ambientes da escola e a integração com outros lugares de aprendizagem. Posteriormente, a comunidade escolar 
decidiu realizar atividades práticas, percorrendo as trilhas indicadas nos mapas. Dessa forma, foi possível vivenciar momentos de aprendizagem pela experiência - caminhar percebendo os lugares, os elementos que compõem a mata, a forma adequada de se comportar no trajeto, os conhecimentos e histórias compartilhados a cada passo. No dia seguinte, os professores e alunos registraram em desenhos os lugares de aprendizagem que mais gostavam, reafirmando que as atividades escolares podem acontecer em toda a $\mathrm{TI}$.

\section{INTERVENÇÕES DE ARQUITETURA JUNTO A POVOS INDÍGENAS}

Consideramos intervenções arquitetônicas as obras executadas em territórios indígenas que visam suprir necessidades construtivas, decorrentes de diferentes fatores. O primeiro deles a ser considerado é a situação de algumas terras destinadas às populações indígenas ou por elas ocupadas, as quais, devido à exploração intensiva decorrente do processo de colonização, não apresentam os recursos necessários à construção, ao artesanato ou às atividades básicas de subsistência. Somados a isso, o contato com a sociedade nacional e a busca pelo respeito aos direitos constitucionais de saúde, educação, moradia, entre outros, geram novas atividades dentro das aldeias, com a necessidade de serem construídos postos de saúde, escolas, instalações sanitárias, infraestrutura de tratamento e abastecimento de água, distribuição de energia etc.

No Brasil, são historicamente recorrentes intervenções arquitetônicas que desconsideram a cultura e o modo de vida das populações indígenas e que interferem em suas formas de organização social e ambiental, o que acaba prejudicando suas atividades cotidianas. As intervenções arquitetônicas e de infraestrutura também podem alterar o modo de vida da comunidade, interferir nas relações políticas, nas suas configurações espaciais e aumentar a dependência da sociedade envolvente. Carvalho (2013) chega a questionar se as intervenções habitacionais em comunidades tradicionais do Pará são uma solução ou um problema, gerado por uma intenção de promoção política.

Sílvio Coelho dos Santos (1975) relata que as iniciativas de assistência agrícola alteravam a relação dos indígenas com sua área de cultivo, alocando novas habitações de modo a configurar vilas que se assemelhavam aos precários núcleos habitacionais das periferias urbanas, eficientes apenas para o controle das atividades dos indígenas pelo agente administrativo do posto. 0 autor retrata uma realidade da década de 1970, anterior à CF-88 (BRASIL, 1988), quando o Serviço de Proteção aos Índios (SPI) objetivava integrar as comunidades indígenas à sociedade nacional. Nesse contexto, foram utilizadas estratégias de controle aplicadas por meio de novas configurações espaciais das habitações inseridas em comunidades indígenas. Apesar disso, o autor relata também comunidades indígenas Mbyá Guarani do Rio Grande do Sul que receberam habitações construídas por iniciativa governamental. Nesse caso, os indígenas justificaram a permanência das construções autóctones devido à representatividade simbólico-cultural delas. Outra justificativa estava relacionada à sustentabilidade cultural e espiritual relacionada à vivência das tradições possibilitada por essas construções - considerando todo o processo construtivo e as relações sociais e econômicas que ele promove, bem como a utilização de materiais carregados de simbologias relacionadas à cosmologia e à própria forma de utilização das construções, o que permite a continuidade do modo de vida Mbyá Guarani.

Amos Rapoport (1983), ao estudar a relação das pessoas com o ambiente, revela preocupações com as mudanças culturais provocadas pelas inovações nos ambientes construídos. Mesmo considerando a dinamicidade das culturas, questiona as mudanças rápidas e drásticas 
decorrentes de intervenções arquitetônicas que não dialogam com as comunidades. O autor considera fundamental o trabalho de pesquisa social anterior à intervenção, para que sejam conhecidas as especificidades culturais e os elementos centrais que precisam permanecer para respeitar o modo de vida das pessoas, mesmo que, no processo, sejam transformados e reinventados pela própria comunidade. Rapoport considera ainda que, se as variáveis culturais são centrais no projeto, o projeto é altamente específico e, então, provavelmente, será impossível generalizar a solução.

Entretanto, para fazer esse tipo de projeto, é necessário interagir com as pessoas diretamente interessadas (aquelas que em arquitetura chamamos de usuários dos ambientes construídos): "Pode existir a necessidade de diminuir o grau de controle do entorno por parte do projetista e de permitir ao consumidor que seja um participante no processo de projeto" (RAPOPORT, 1971, p. 310-1,tradução nossa). O autor aponta para possibilidade de fluidez no processo e de participação direta dos futuros usuários. Embora possa parecer pouco eficiente, por considerar o tempo de desenvolvimento maior para o projeto, entre outras dificuldades de controle do processo ao contar com os aportes dos usuários, esse tipo de encaminhamento pode trazer resultados mais próximos das necessidades e expectativas das pessoas. Além disso, as soluções certamente não serão "pasteurizadas", como acontece com projetos padronizados, que, embora favoreçam a agilidade do processo, não permitem alterações ou adequações significativas.

Krinsky (1996, p. 180, tradução nossa), ao analisar a realidade norte-americana, considera que soluções padronizadas impostas, externas à comunidade indígena, raramente atingem seus objetivos, porque os usuários não adotam os resultados como seus: "Imposição' (por coerção ou por suborno benevolente na forma de uma casa gratuita) é a palavra-chave aqui, porque os indígenas deveriam ser tão livres quanto qualquer outro povo para aceitar um padrão predeterminado, caso eles o considerem adequado".

Partindo do referencial teórico aprofundado na pesquisa (RAPOPORT, 1971, 1983, 2003; MALNAR; VODVARKA, 2013; KRINSKI, 1996; SÁ, 2002), destacamos alguns pontos que contribuem para o desenvolvimento de projetos arquitetônicos junto a grupos indígenas: pesquisa de campo anterior; flexibilidade no processo; equipe interdisciplinar; participação indígena no processo de projeto; linguagem intercultural flexível; recursos de representação manipuláveis; tempos flexíveis; tomada de decisão de acordo com as práticas locais; conceito do projeto definido a partir do entendimento dos processos construtivos e de organização social de cada comunidade, sendo contextualizado na contemporaneidade.

Como nosso objeto de estudo foi uma escola indígena, apresentamos, a seguir, algumas reflexões sobre a presença da escola nas aldeias e sua relação com a educação vivenciada no contexto das comunidades, que auxiliam na análise dos ambientes utilizados pela Escola Itaty e na identificação dos lugares de aprendizagem que se expandem pelo território.

\section{AMBIENTES ESCOLARES INDÍGENAS}

As primeiras escolas para povos indígenas no Brasil remontam às iniciativas educativas e civilizadoras das missões religiosas e objetivavam a assimilação cultural dessas populações, de modo a integrá-las à sociedade nacional. A República trouxe ideais positivistas de progresso e modernização do país, sendo criado, em 1910, o Serviço de Proteção aos Índios e Localização de Trabalhadores Nacionais (SPILTN), responsável pela pacificação, reserva, educação e civilização das populações indígenas para tornarem-se trabalhadores nacionais (TASSINARI, 2008). A criação 
da Fundação Nacional do Índio (FUNAI), no fim da década de 1960, fomenta o ensino bilíngue com monitores indígenas, como uma forma de facilitar a transição para a assimilação deles à sociedade nacional. Porém isso desencadeia movimentos pelo reconhecimento dos direitos indígenas, que culminam na Constituição Federal de 1988, ampliando o entendimento dos povos nativos de que a educação pode ser um meio para assegurar esses direitos, por possibilitar a ampliação do diálogo com a sociedade envolvente e a afirmação de suas identidades étnicas (BRAND; CALDERONI, 2012; ALTINI et al., 2014). A partir de então, foram sendo criados meios de efetivar uma educação diferenciada, bilíngue e intercultural, que valorizasse as culturas nativas, sendo a Lei de Diretrizes e Bases da Educação Nacional (LDBEN), de 1996, o marco para uma nova fase na educação indígena do país (TASSINARI, 2008).

O reconhecimento dos direitos indígenas a uma educação que contemple "suas línguas maternas e processos próprios de aprendizagem" (BRASIL, 1988, Art. 210. § 2º) proporcionou avanços gradativos em direção a uma educação escolar indígena construída com a participação da comunidade na definição de suas características, inclusive com relação aos espaços físicos (BRASIL, 1999, 2012). Regulamentações e legislações mais recentes orientam que o desenho arquitetônico das escolas indígenas considere as práticas construtivas do grupo e suas formas próprias de uso do espaço (BRASIL, 2007, 2014). Indicam, também, que o espaço escolar não deve ser restrito às estruturas físicas construídas para tal, uma vez que o aprendizado indígena está vinculado aos ambientes naturais e construídos que integram o contexto da comunidade.

No caso das escolas indígenas em que a comunidade participa efetivamente da escola, o ambiente físico precisa abrigar encontros e atividades que são parte das vivências culturais e extrapolam o uso dado ao espaço em escolas convencionais. Representantes indígenas reclamam da falta de espaços específicos que permitam integrar, no cotidiano da escola, atividades da comunidade que fazem parte do aprendizado das crianças, considerando, ainda, a educação contínua ao longo da vida e entre gerações. Os professores indígenas explicitam o desejo de integrar, no espaço escolar, as formas próprias de aprendizagem em sua relação com os costumes, com as tradições, com a forma de ver o mundo, de viver e de se relacionar com todos os seres e elementos que o compõe (SILVA, 2014).

Um dos questionamentos de professores e gestores de escolas Guarani assenta-se no modelo de escola proposto nas aldeias, em seu engessamento, apesar de a legislação garantir autonomia das comunidades na administração dos tempos e espaços escolares. Em um encontro da Ação Saberes Indígenas na Escola ${ }^{4}$, as vozes dos Guarani e dos juruá (não indígenas) que trabalham nas escolas apontaram a dificuldade em negociar a flexibilidade e legitimidade de tempos e espaços de aprendizado que estão fora do padrão estabelecido ou aceito pelas secretarias e gerências de educação. Um dos argumentos era em defesa das atividades realizadas na Opy (Casa de Rezas), junto aos xeramõi (anciões, sábios), que deveriam ser valorizadas e consideradas como horário letivo, devido à sua relevância na educação das crianças e dos jovens. Se a escola não considera esses tempos e espaços, então as crianças passarão muito tempo na escola, deixando de vivenciar práticas culturais fundamentais para seu aprendizado junto à comunidade. Acontece, nesse caso, uma sobreposição de valores e de saberes, em uma disputa por tempos e espaços.

\footnotetext{
${ }^{4}$ Ocorrido nos dias 17, 18 e 19 de novembro de 2016, na Tekoá I'vya, em Major Gercino, SC. O evento foi organizado pela equipe da Ação Saberes Indígenas na Escola (MEC/UFSC).
} 
Mesmo com o surgimento de formas de ensino que buscaram romper com o caráter disciplinador da educação escolar, ainda permanecem, hoje, muitas características de controle de tempos e espaços, as quais estão presentes no imaginário do que é uma escola, essa chamada "cultura escolar" (FARIA FILHO, 1998), que vem se reproduzindo ao longo da história. Contudo os processos de aprendizagem indígena, ao ingressarem na escola, subvertem algumas cristalizações do senso comum relacionadas ao uso dos tempos e espaços, possibilitando novas abordagens em uma legítima "indianização da escola" (BERGAMASCHI, 2007). A autora observa, com relação ao uso dos espaços para o ensino em uma escola Guarani, que não são necessariamente utilizadas salas com esse fim específico, mas podem acontecer aulas no centro cultural ou passeando pela aldeia. Além disso, não há rigidez nos tempos de chegada e de término das aulas. Existe um fluir da atividade, as crianças chegam, acompanhadas dos irmãos menores, e ficam na escola enquanto permanece o "encanto" (BERGAMASCHI, 2005).

É interessante constatar, para além das apropriações dos espaços que estão dados como escolares, o movimento de transformação e construção de novos espaços, a inserção de elementos arquitetônicos simbólicos dentro ou adjacentes ao espaço escolar, para que sejam utilizados em atividades para as quais o espaço da sala de aula é inadequado. Um exemplo disso é a construção de Casas de Reza em tamanho reduzido (Opy Mirĩ), para serem utilizadas pelas turmas em algumas escolas Guarani. O próprio movimento de construção da OpyMirĩ é educativo, pois faz parte do aprendizado de crianças e jovens. O processo construtivo retira-os dos ambientes fechados para coletarem na mata os materiais para a construção. Trabalham em grupo, com persistência, em uma atividade real, que precisa ser finalizada. Estão em contato com diversos materiais, seus cheiros, pesos, texturas e significados simbólicos. Aprendem etnomatemática, etnobiologia, história do território, reforçam suas crenças, seus valores. Depois, esse espaço por eles construído torna-se um lugar apropriado para a presença de elementos sagrados que fazem parte da educação Guarani: o tata (fogo), o petyngua (cachimbo ritual), o piso de terra, a cobertura de taquara - por meio da qual se eleva a fumaça (tataxinã) do fogo e do cachimbo.

Nas manifestações de representantes indígenas, percebemos clareza na compreensão do papel da escola na sociedade envolvente e qual escola querem em suas aldeias: uma escola efetivamente indígena, que respeite seus tempos, seus ritmos, seus lugares de aprendizagem, os quais se expandem para além das paredes que limitam os espaços ditos "escolares". A educação escolar deve estar comprometida com a educação vivenciada no cotidiano da comunidade. As pessoas entram e saem, os animais também, o sol, a chuva, todos os seres e elementos estão presentes em seus percursos, em seu fluir, em seus encontros e trocas.

\section{INTERVENÇÃO ARQUITETÔNICA PARA A ESCOLA ITATY}

Para analisar essa intervenção arquitetônica, partimos das considerações de Borges (2002, p. 110) acerca do tempo (dimensão do movimento e da duração) e do espaço (lugar das coisas), sobre como o tempo interfere na configuração dos lugares, em suas "sucessivas transformações", que implicam a destruição e criação de formas para a emergência do novo. Compreendemos que o tempo e o espaço integram a análise de uma intervenção arquitetônica, pois somente com o estudo das mudanças ocorridas ao longo do tempo podem ser identificados os impactos da intervenção e as respostas de apropriação encontradas, que se apresentam como transformações nos lugares (POL, 1996). 
No caso analisado, constatamos que a ocupação espacial foi se alterando em decorrência de intervenções de infraestrutura, como a abertura da BR-101, que se soma à instalação de redes de distribuição de energia e, juntamente da construção e do início de funcionamento da escola, foi condicionando e definindo as áreas "adequadas" para a construção de novas moradias. Abordaremos especificamente a influência da Escola Itaty no desencadeamento dessas transformações espaciais, buscando compreender como era a ocupação do Morro dos Cavalos antes da construção da escola e as alterações ocorridas após sua inauguração.

A arquitetura escolar específica para educação indígena iniciou-se no estado de Santa Catarina em decorrência das legislações e normativas criadas a partir da CF-88 e de um cenário político favorável. A Secretaria de Estado de Educação de Santa Catarina (SED/SC), com a atuação do Núcleo de Educação Indígena (NEI) e com o apoio de instituições como a Universidade Federal de Santa Catarina (UFSC) e a Universidade do Estado de Santa Catarina (UDESC), passou a ter uma compreensão mais ampla das diferentes etnias indígenas presentes no estado. Nesse cenário, uma conjunção de fatores possibilitou a construção da Escola Itaty, que foi inaugurada na Tekoa Itaty em 2002 e que fica localizada nas margens da Rodovia BR-101, no km235.

Embora estivéssemos motivadas a conhecer como aconteceu o processo de projeto arquitetônico, como ocorreu a participação dos Guarani, como suas aspirações com relação à arquitetura da escola foram traduzidas em projeto arquitetônico, ao longo da pesquisa, identificamos alguns fatores que dificultaram esse diálogo, como: o ritmo e a lógica de funcionamento das instituições governamentais, que diferem dos ritmos e das formas de diálogo dos Guarani; apesar da abertura e da sensibilidade das arquitetas e da equipe da SED/SC para compreender as necessidades e expectativas dos Guarani, estavam presentes o ineditismo da situação e a inexperiência nesse tipo de diálogo (tanto para os técnicos quanto para a comunidade); ingerências durante o processo (como a escolha do local e alterações do projeto durante a obra), provocadas por diferentes atores; além disso, o financiamento e o desenvolvimento do projeto por instâncias governamentais indicam que a comunidade tinha pouco controle sobre o resultado final da obra.

As arquitetas responsáveis pelo projeto arquitetônico estavam abertas para o diálogo tanto com as lideranças quanto com os pesquisadores. Apesar disso, não ocorreu um processo colaborativo que possibilitasse à comunidade definir a concepção arquitetônica da escola. Foram apresentados desenhos, mas não foram produzidas maquetes ou utilizadas outras ferramentas para auxiliarem nos diálogos. O partido arquitetônico contemplou as orientações recebidas, utilizando o formato circular e a separação dos espaços construídos, proporcionando liberdade na configuração dos ambientes externos (Figuras 1 e 3). A distribuição das salas de aula assemelhase à forma de ocupação dos núcleos familiares, em que o refeitório corresponderia à cozinha aberta onde os integrantes da família se reúnem junto ao fogo de chão. A maioria dos materiais escolhidos preza pela durabilidade, mesmo procurando utilizar madeira como um material mais natural. 
Figura 1 - Implantação da Escola Itaty e entorno imediato (sem escala)

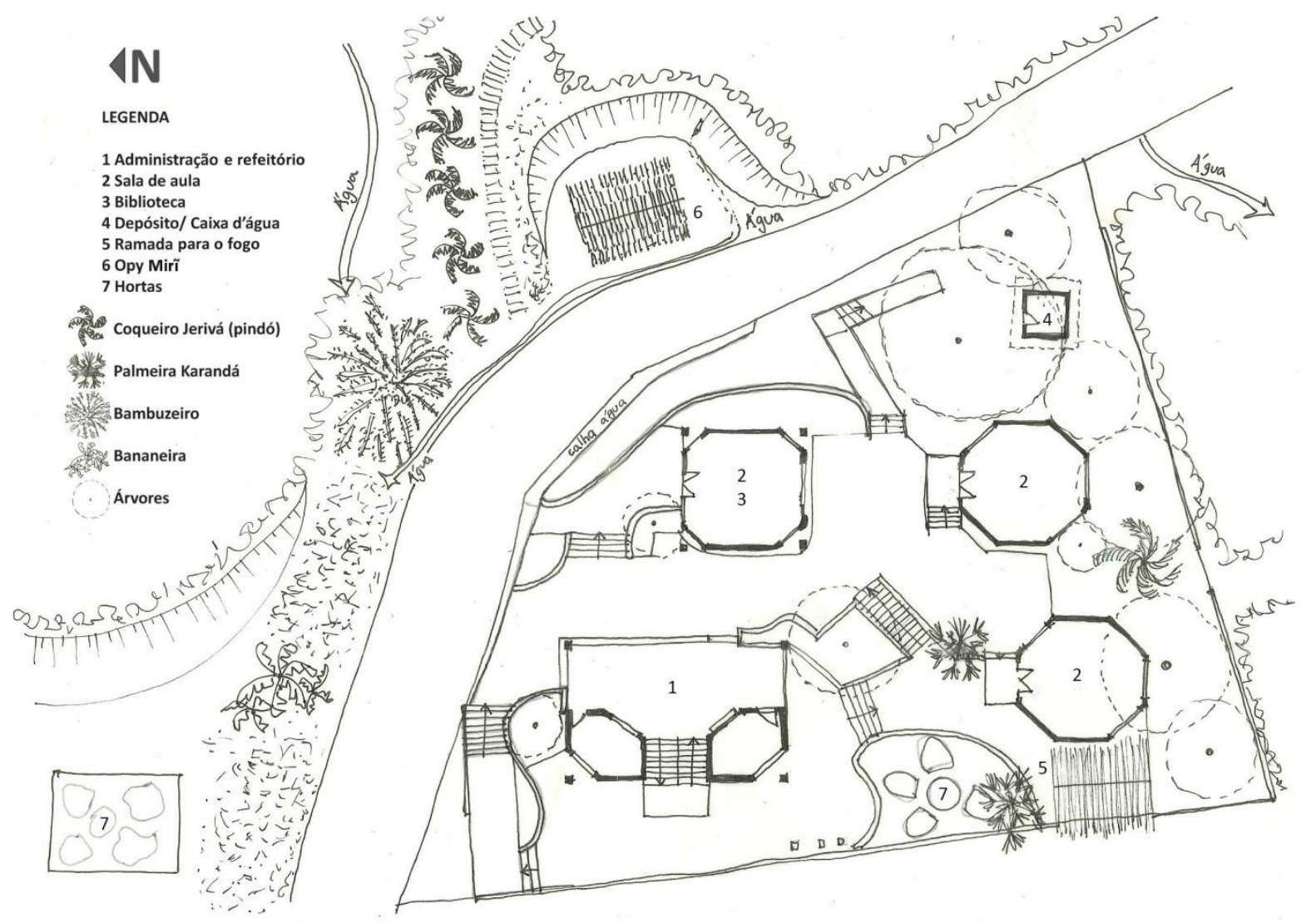

Fonte: Elaborado pelas autoras a partir do projeto arquitetônico.

Em um grupo focal desenvolvido com os professores Guarani da Escola Itaty, em junho de 2017, identificamos que, antes de essa escola ser construída, as famílias viviam em quatro aldeias, duas localizadas no morro leste e duas no morro oeste (Figura 2). Nessa época, as aldeias ficavam no alto dos morros, distantes da rodovia. No morro leste, havia uma escola pequena, conduzida pelos Guarani, em uma casa de madeira, com piso de chão batido, considerada "escola verdadeira" 5 . A aldeia mais antiga, localizada no morro oeste, era de difícil acesso e foi habitada até o ano de 2003, depois de iniciarem as atividades na Escola Itaty, o que desencadeou grandes transformações na organização espacial das aldeias do Morro dos Cavalos. A escolha do local para a construção da escola, junto à rodovia, também teve uma grande relevância, pois, no momento em que a escola começou a funcionar, ela atraiu para perto de si as moradias das famílias, desarticulando a organização anterior, em que famílias extensas viviam em várias tekoa (lugar adequado para viver o modo de vida Guarani). 
Figura 2 - Mapa de ocupação do território antes da construção da Escola Itaty

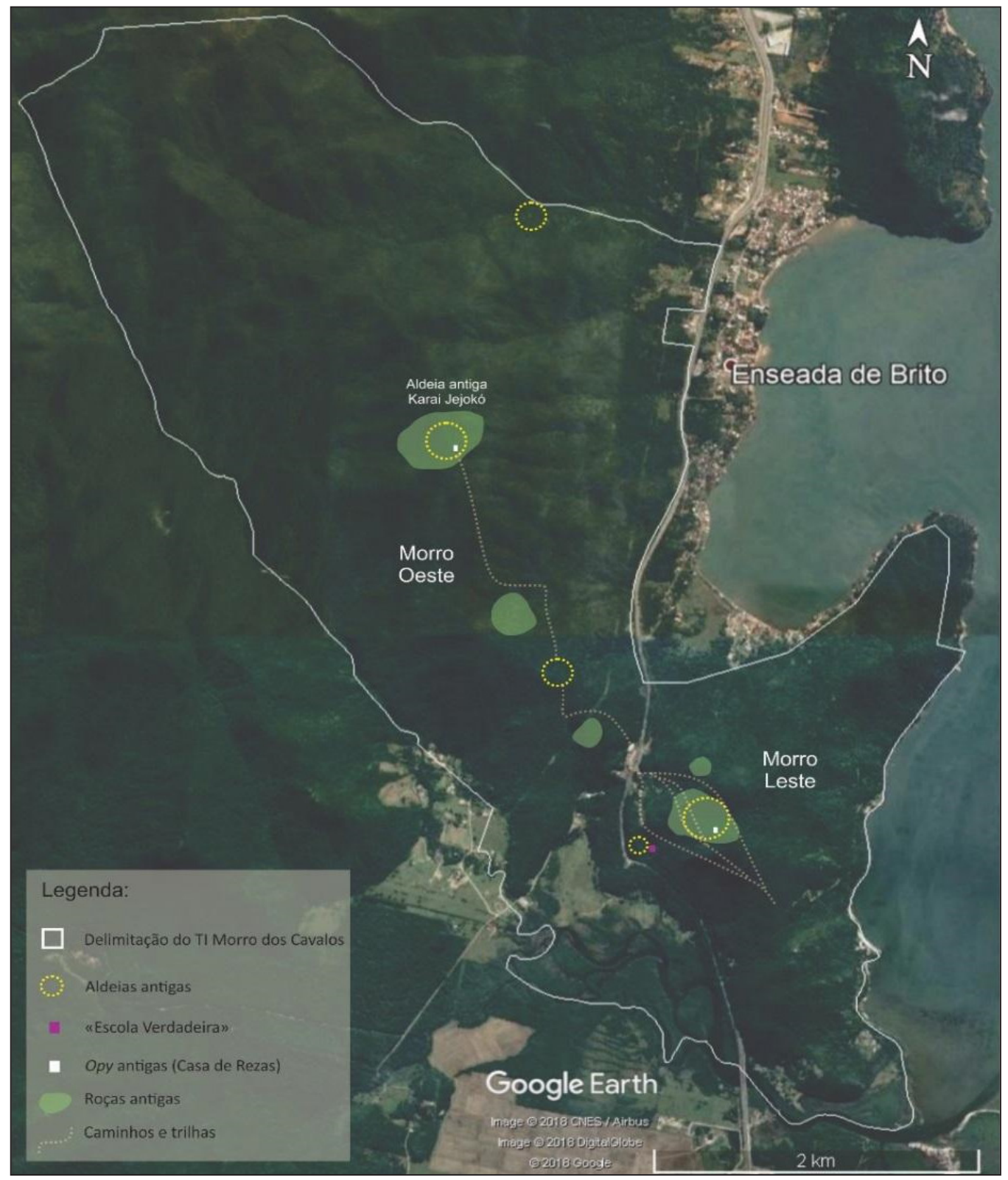

Fonte: Foto de satélite do Google Earth (2018) com a delimitação da TI segundo a FUNAI. Imagem editada por Nauíra Zanardo Zanin, com base no mapeamento realizado por professores da Escola Itaty.

A escola foi construída junto à Rodovia BR-101, que tem fluxo intenso de veículos pesados. Mesmo que seus espaços principais não estejam voltados para a rodovia, o ruído dos veículos de carga invade os ambientes escolares de forma agressiva, interrompendo as aulas (Figura 4). Essa invasão sonora demonstra claramente a permeabilidade a que estão expostos, na interação com o ambiente em que se inserem (INGOLD, 2015), principalmente pela presença e proximidade da rodovia. Observamos que essa proximidade, além de permitir a invasão de ruídos e gases tóxicos, facilita que pessoas estranhas abordem a comunidade. A partir do referencial teórico (BERGAMASCHI, 2005; TASSINARI, 2001; BENITES, 2015), compreendemos que a escolha do lugar para a construção da escola possibilita relacionar, para além do campo conceitual, o espaço físico da Escola Itaty com a interculturalidade que flui pela fronteira "rodovia-aldeia", sendo a escola o lugar de encontro, de negociação - a "embaixada". 
Figura 3 - Refeitório aberto da Escola Itaty

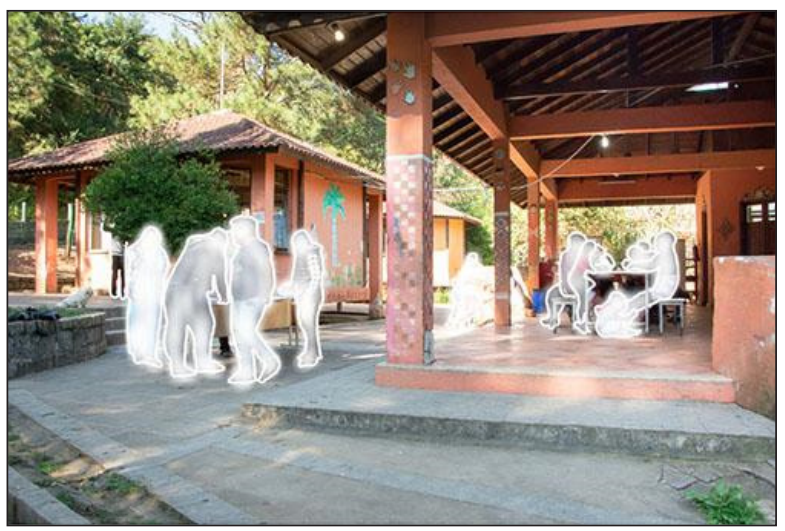

Foto: Nauíra Zanardo Zanin.
Figura 4 - Trânsito de veículos pesados na BR101 e sua proximidade com relação à Escola Itaty

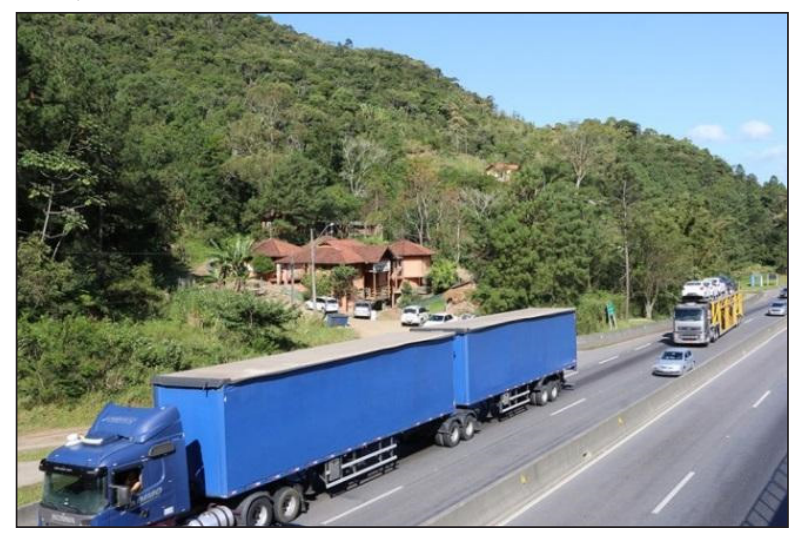

Foto: Nauíra Zanardo Zanin.

Os entrevistados não indígenas e os interlocutores Guarani expressaram que a escola deveria ter sido construída em cima do morro, mais próxima das casas e mais afastada da rodovia. Unwin (2013) ressalta a responsabilidade daqueles que definem a escolha do lugar para os outros. Frago (2001) manifesta que o espaço jamais é neutro e, sendo o lugar um espaço habitado, simbolizado, carregado de memórias e de intenções, percebemos, ao longo da pesquisa, que a escolha do lugar para a construção da escola também não foi neutra, mas movida pela intenção de tornar visível tanto o povo Guarani que habitava o Morro dos Cavalos como a ação governamental.

Além disso, vários entrevistados mencionaram as dificuldades enfrentadas para que ocorresse a construção da escola, pois a TI ainda não era reconhecida. Um entrevistado que era integrante do Conselho Estadual dos Povos Indígenas de Santa Catarina (CEPIN/SC) na época do projeto esclareceu que a escolha da localização deveu-se ao fato de não ter sido ainda demarcada a terra indígena e haver uma superposição de autoridades sobre a faixa próxima da rodovia. O terreno foi escolhido porque ficava entre a faixa de domínio da rodovia e da linha de distribuição de energia e, ao mesmo tempo, não adentrava na área de mata que integrava o Parque Estadual da Serra do Tabuleiro. Depois da construção da escola, as casas "desceram o morro", sendo construídas mais próximas à BR-101 (Figura 5). Os entrevistados expressaram claramente (tanto os Guarani quanto os não indígenas) que a escola foi o maior motivador dessa mudança. A professora Kerexu detalha os motivos que influenciaram na localização atual das moradias:

Como a nova escola tinha ficado muito distante das casas e foi instalado o ensino obrigatório em dois turnos, diferenciando as idades, tinha ficado mais difícil para as familias deslocaremse subindo e descendo os morros todos os dias, várias vezes por dia, com as crianças. Esse foi um motivo que levou as famílias a morarem perto da escola. [...]quando o DNIT foi construir as casas novas, limitou-as a uma faixa entre a área de domínio da BR-101 e a área de domínio da rede de transmissão de energia. Por isso, as casas estão localizadas onde estão hoje. (Conversa com Kerexu, Diário de Campo, 09/06/2017). 
Figura 5 - Mapa sobre foto de satélite indicando a área de ocupação mais intensa da TI Morro dos Cavalos (Tekoa Itaty) junto à Escola Itaty

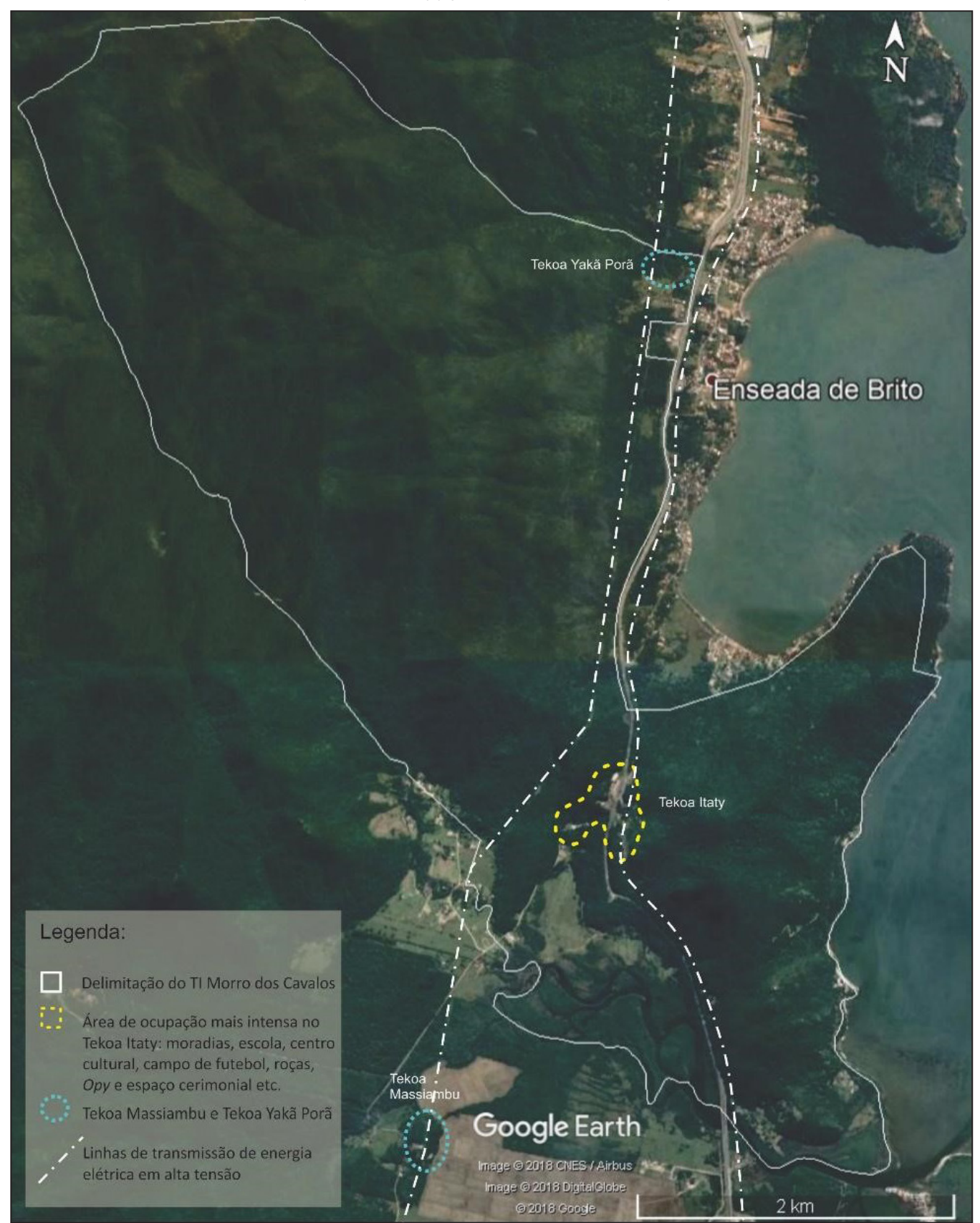

Fonte: Foto de satélite do Google Earth (2018) com a delimitação da TI segundo a FUNAI, editada por Nauíra Zanardo Zanin, com base no mapeamento realizado por professores da Escola Itaty.

No documentário "Mbyá Guarani: guerreiros da liberdade" (MBYA, 2004), observamos que, quando foi inaugurada a Escola Itaty, as salas de aula eram repletas de classes escolares, pesadas, em madeira, com o assento fixo à classe, exercendo o controle e a docilização de corpos e mentes, como criticado por Foucault (1987), entre tantos pensadores da educação. Essa forma de educar diferia muito da vivenciada na antiga "escola verdadeira", localizada no alto do morro. Dessa forma, fica o questionamento: como aquelas crianças Guarani receberam essa mudança? Essa nos parece algo drástico entre o aprender da "experiência" (BONDÍA, 2002) e o estar confinado por determinado tempo em um espaço restrito e barulhento. 
Realmente, os entrevistados relatam que logo perceberam que aquela forma de educação não era a desejada por eles.

A professora Kerexu $u^{6}$ revela que a educação escolar chegou à aldeia controlando e mudando drasticamente suas vidas, mudando suas casas de lugar, regrando e limitando seus deslocamentos pelo território, seu aprendizado vivenciado no movimento e no deixar-se permear, com todos os sentidos, pelos lugares e pelo percurso (INGOLD, 2000, 2015). Ela destaca as restrições sofridas, mas destaca como os Guarani criaram meios de desviarem-se do controle para respeitarem seu modo de vida, mesmo que os outros não respeitassem. Também revela a potência da educação Guarani em um momento em que, cada vez mais, questiona-se o sistema educacional vigente ou os modos de ensinar originados séculos atrás (GEORGEN, 2005).

A professora relembra, em detalhes, o que aconteceu ao propor como atividade escolar que as crianças aprendessem, na prática e na mata, com um ancião Guarani (xeramõi). E também está muito viva a memória do conflito, da "luta" que foi travada pelos representantes do "ensino formal", tentando manter as crianças nas salas de aula, considerado o lugar "legítimo" para o ensino acontecer. Até esse momento, consideramos que os Guarani utilizavam a escola, mas ainda não tinham se apropriado dela. Somente com a mudança da gestão da escola, iniciouse o processo de apropriação. E isso remete às palavras de Fuão (2014), ao expressar que o acolhimento não depende somente do lugar, mas também das pessoas e das relações que lá se estabelecem.

Antunes (2015) relata a longa trajetória para que a comunidade conseguisse aprovar seu projeto político-pedagógico (PPP) e finalmente ter reconhecido seu modo de ensinar. Foi somente no fim do ano de 2012 que a comunidade conseguiu que a SED/SC considerasse o documento entregue como um PPP válido. O funcionamento da escola, na organização de seus tempos e espaços, não tem regramentos rígidos, permitindo a presença das famílias e o convívio em sala de aula de crianças de diferentes faixas etárias, não somente pelo fato de serem aulas multisseriadas. As aulas acontecem nas salas de aula, em espaços construídos pela comunidade escolar e também nos ambientes do entorno da escola e para além dela.

A apropriação pode ser observada pela liberdade com que utilizam internamente as salas de aula, mas também os espaços do pátio, para jogos de vôlei, brincadeiras, danças e até mesmo a venda de artesanato ao receberem visitantes (Figuras 6 e 7). Alguns sinais de apropriação consistem em símbolos, grafismos, desenhos e outras personalizações nas paredes da escola, produzidos pela comunidade escolar. São imagens que revelam a personalização "resultante da conduta territorial de um sujeito ou um coletivo enquanto ocupam, defendem e experimentam um forte sentido de identificação e pertencimento com um espaço" (BROWER apud POL, 1996, p. 16). 
Figura 6-Jogo de vôlei entre as salas da escola

Figura 7 - Venda de artesanato durante a Semana Cultural

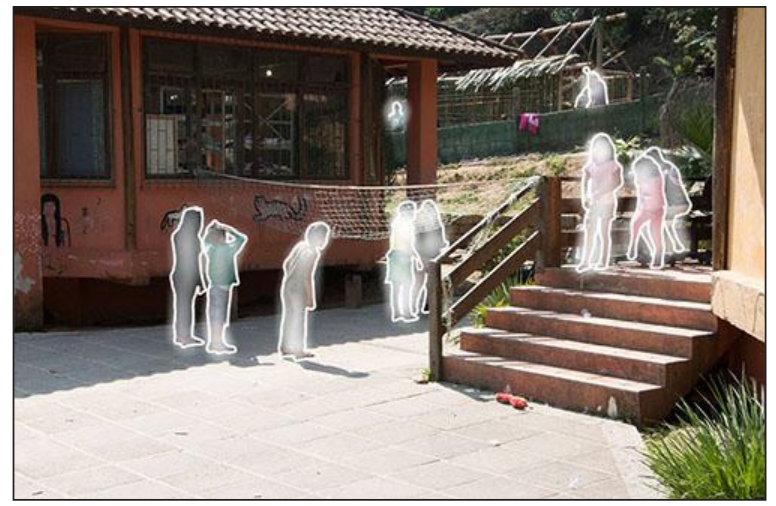

Foto: Nauíra Zanardo Zanin.

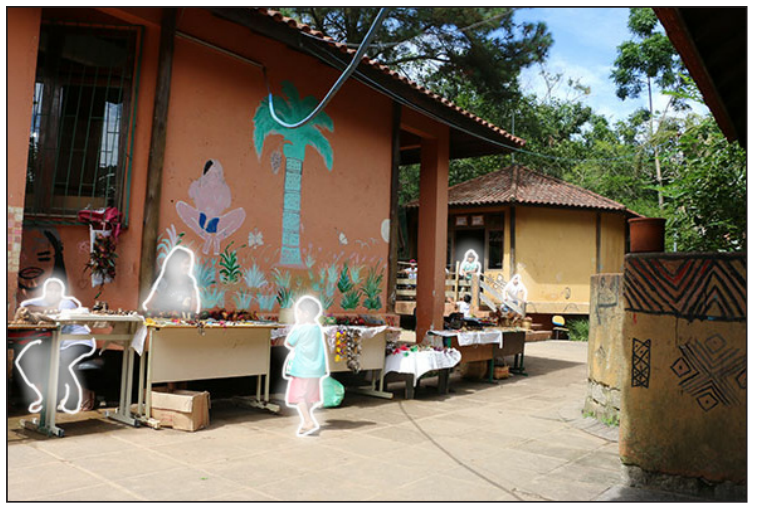

Foto: Nauíra Zanardo Zanin.

Portanto, depois que foram resolvidas as questões relacionadas à gestão da escola, os Guarani esforçaram-se por legitimar seus modos próprios de educar, seus "processos próprios de aprendizagem", como previsto na CF/88. Essa é a forma de uso e apropriação do espaço que observamos na Escola Itaty, o que nos leva a considerar, comparando com outras escolas indígenas com desenho específico, que o desenho arquitetônico pode, sim, facilitar a apropriação espacial, tornando o espaço escolar um lugar onde acontece a educação (escolar e Guarani). Porém é importante considerar que isso não acontece em todas as comunidades Guarani, porque, em algumas, a escola é somente uma obrigação formal. Entretanto, na Tekoa Itaty, durante o período da pesquisa, observamos e escutamos a confirmação de que a escola era o centro da comunidade.

\section{LUGARES DE APRENDIZAGEM QUE INTEGRAM O TERRITÓRIO À EDUCAÇÃO ESCOLAR}

Durante a pesquisa, também conversamos com os professores Guarani sobre os ambientes de aprendizagem que são utilizados nas atividades escolares, mas que se estendem a outros lugares da TI. Observamos que foram construídos, pela comunidade, alguns espaços nos quais é possível utilizar o fogo na escola, como uma cobertura de pindó (Figura 8) e a Opy Mirĩ (Figura 9), uma Casa de Rezas demonstrativa - casa de cultura - construída como ampliação do espaço da escola, para possibilitar a educação Guarani. Ainda assim, as atividades educativas extrapolam os espaços escolares restritos pela arquitetura, utilizando outros lugares que também passam a ser parte dos ambientes escolares, como quando os alunos e professores foram na mata coletar material para a construção da Opy Mirĩ ou quando se deslocaram até o Centro Multicultural Tataendy Rupa para fazerem o plantio das roças (kokue) na época da primavera - Ara Pyau. 
Figura 8 - Ramada para o fogo, em 2016, coberto com pindó e karandá

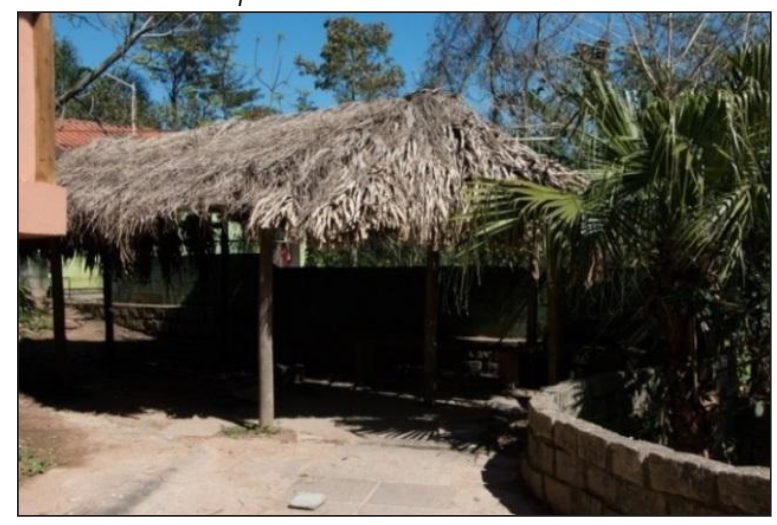

Fotos: Nauíra Zanardo Zanin.
Figura 9 - Opy Mirĩ sendo reconstruída junto à Escola Itaty, em agosto de 2016

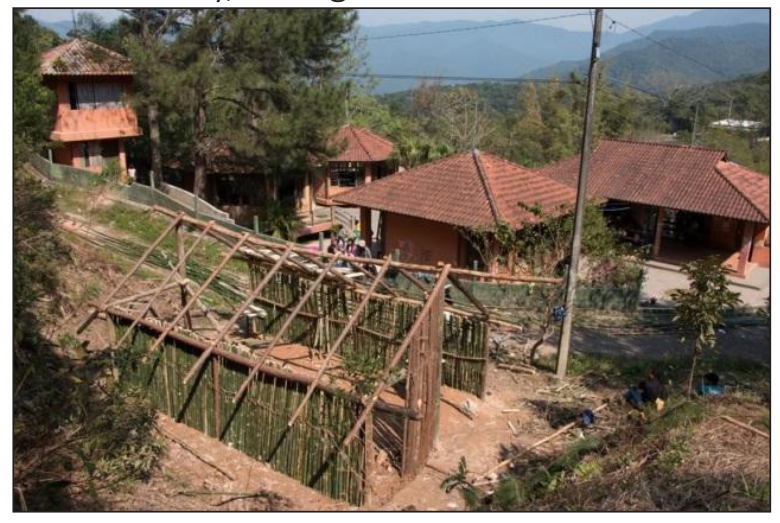

Foto: Nauíra Zanardo Zanin.

A variedade de lugares utilizados no aprendizado escolar observado na Escola Itaty está relacionada com seus usos tradicionais e com as ocupações anteriores. Nas atividades realizadas com os Guarani, como trilhas na mata conduzidas por professores e estudantes da Escola Itaty, é notável o conhecimento que eles têm das plantas, das árvores, dos animais e dos lugares em que se encontram. Ao caminharem pelos morros, seguem expressando conhecimentos sobre as características de cada lugar e é possível perceber as mudanças nos ruídos e cheiros da mata. Eles sabem onde buscar água boa para beber e o uso que pode ser dado para cada planta. $\mathrm{O}$ caminho está repleto de histórias e memórias, deste e de outros lugares.

Na Figura 10, estão identificados os lugares de aprendizagem onde foram coletados os cipós, os pinus e a taquara para a construção da Opy Mirĩ. São lugares que correspondem às antigas aldeias e roças, que passam a ser identificados como ambientes escolares, assim como as trilhas que conduzem até eles. 
Figura 10 - Mapa dos lugares de coleta de materiais utilizados nas atividades escolares

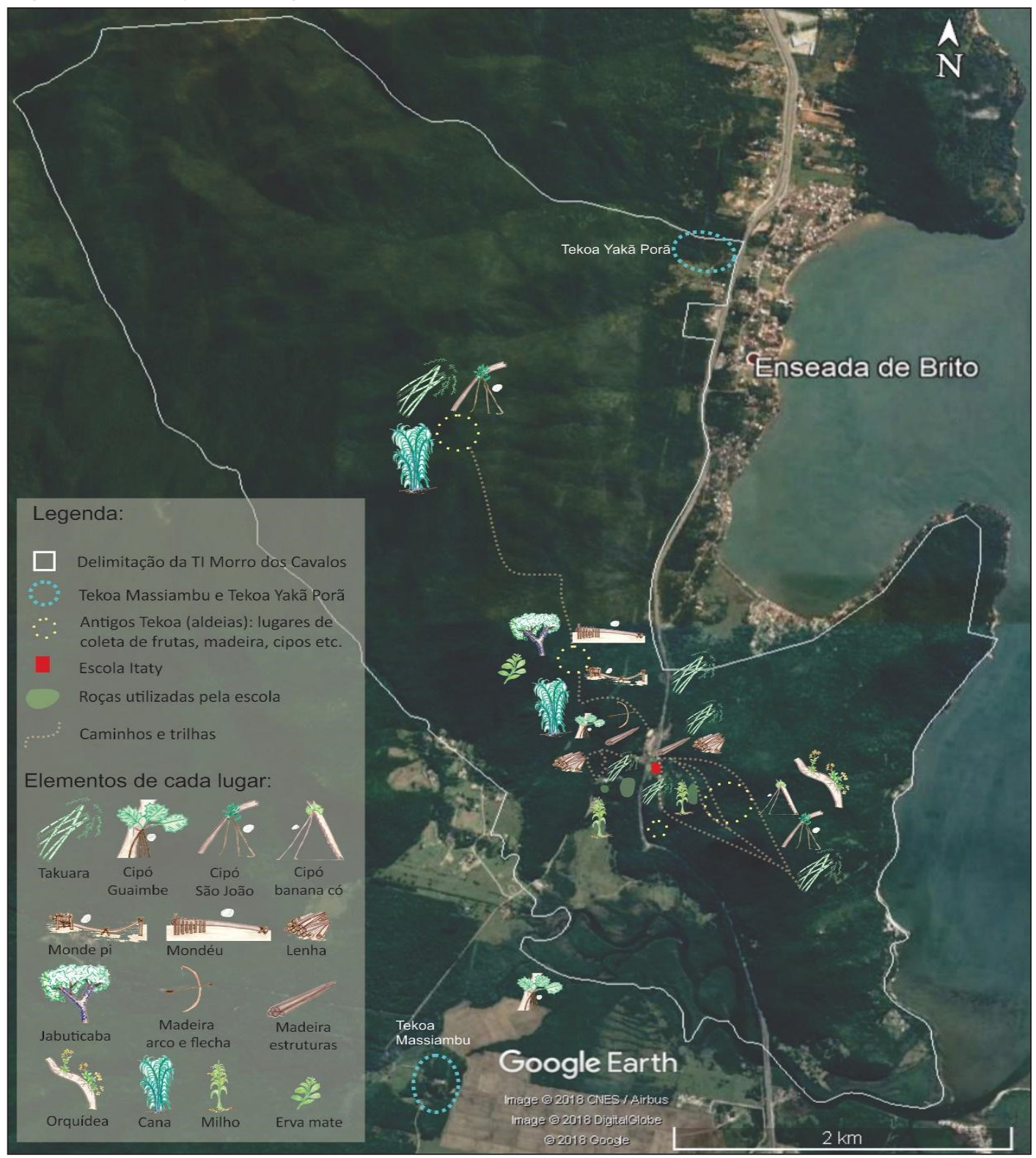

Fonte: Foto de satélite do Google Earth (2018) com a delimitação da TI segundo a Funai. Imagem editada por Nauíra Zanardo Zanin com base no mapeamento realizado por professores da Escola Itaty. Desenhos da legenda: Jaxuka e Nauíra Z. Z.

Um aspecto importante destacado pelo ex-diretor ${ }^{7}$ da Escola Itaty é a presença do território na escola. Ele considera que o espaço - não delimitado - da escola é concebido a partir da noção de território, nos termos em que os Guarani vivenciam a apropriação simbólica do espaço - a vida no tekoa segundo o nhanderekó (nosso sistema; modo de vida Guarani). O território está na escola, e a escola está no território; portanto as atividades escolares podem ser em qualquer lugar.

As salas de aula, o refeitório, os recantos do pátio, o fogo coberto, a Opy Mirĩ e as hortas são todos lugares claramente vinculados às atividades escolares da Tekoa Itaty. Ainda assim, o processo educativo Guarani não se limita a esses lugares - que não foram por eles escolhidos e recebem influência direta da BR-101. Portanto, para inserirem a educação Guarani nas atividades

\footnotetext{
${ }^{7}$ Entrevista realizada na SED, em 31/03/2017.
} 
escolares, a comunidade escolar não permanece na escola e no seu entorno imediato. Inclusive, para construírem e transformarem esse entorno a fim de melhor apropriarem-se dele, precisam circular pelo território, coletando os materiais necessários. Todo o contexto em que vivem tornase parte dos ambientes escolares. Nesse movimento, que integra a educação e o modo de ser Guarani, eles se deslocam por trilhas na mata, as quais são antigos caminhos que permanecem por serem necessários, uma vez que os conduz para onde estão os frutos, os cipós, as árvores, as plantas medicinais e os animais. Esses caminhos conduzem-nos, também, pela história de ocupação dos morros dessa terra indígena. É no lugar das aldeias antigas, das roças antigas, que encontram aquilo de que necessitam para educar as crianças e os jovens. E é também no percurso, no deslocamento pela mata, que muitas memórias surgem e o conhecimento e a sabedoria são compartilhados e vivenciados.

Apesar disso, os lugares de aprendizagem, conforme observado, não se restringem à TI Morro dos Cavalos. Aldeias vizinhas ou distantes são lugares que precisam ser periodicamente visitados, pois nelas buscam sementes para plantar e compartilham vivências com seus parentes. Contudo esse aprendizado também não se restringe ao sistema Guarani, ao nhandereko. O aprendizado é intercultural, o que implica estar disponível para o convívio e o aprendizado com o outro. E são muitas as oportunidades para aprender com e sobre os jurua: deslocando-se de ônibus; vendendo artesanato no centro da cidade; cantando com o coral no centro ou em eventos; participando de feiras e eventos realizados em centros urbanos ou em instituições como universidades, escolas, empresas públicas, organizações não governamentais (ONGs), entre outros.

Ao observar as práticas escolares realizadas na Tekoa Itaty e escutar as vozes dos Guarani, torna-se evidente o vínculo de sua forma de educar com o conhecimento que é transmitido, de geração em geração, sobre o território em que vivem, deslocam-se, encontram-se, transformamse, dando seguimento aos passos dos antigos ${ }^{8}$, às memórias de histórias que seguem sendo contadas. Não são somente mitos, mas histórias de pessoas reais, que caminharam nesse território e viveram nesses lugares em gerações precedentes. Foi isso o que escutamos e é como entendemos que procuram conduzir seu modo de viver e de ensinar: respeitando os lugares por onde caminharam seus ancestrais.

\section{CONSIDERAÇÕES FINAIS}

Constatamos que "mesmo em uma intervenção que se diz voltada aos interesses indígenas, a arquitetura, a mudança na configuração espacial altera também as relações sociais e culturais relacionadas ao ambiente" (Diário de Campo, 02/06/2017), como aconteceu na Tekoa Itaty. Consideramos que o desenho arquitetônico, mesmo que não tenha contemplado uma participação mais ativa dos Guarani, apresenta soluções que facilitam a apropriação e as formas de uso desejadas pela comunidade. A liberdade e a fluidez na conexão entre os espaços abertos e fechados, inclusive pela grande quantidade de aberturas, somadas às construções que os Guarani fizeram para obter um melhor aproveitamento dos ambientes da escola, conferem flexibilidade e dinamicidade às formas de uso, possibilitando que atividades diversificadas ocorram: plantio de horta, preparo de alimentos tradicionais, ensaio e apresentações de canto e dança, jogos de vôlei, venda e exposição de artesanato, alimentação coletiva, atendimento médico, reuniões da

\footnotetext{
${ }^{8}$ Como se referem aos seus antepassados, aos que vieram primeiro.
} 
comunidade, festas e eventos, exibição de filmes, aulas práticas de artes e artesanato e aulas teóricas nas salas de aula, entre outros. Pol (1996, p. 12, tradução nossa) oferece argumentos a favor do desenho específico ao considerar que "[...] as características do espaço, sua rigidez ou flexibilidade, sua contraposição ou sintonização com o coletivo usufrutuário, podem ser fatores facilitadores ou dificultantes [da apropriação]".

Os processos próprios de aprendizagem aparecem na escola de forma sutil, muitas vezes não explícita, como no modo de os professores conversarem com os estudantes. Entretanto, para essa pesquisa, houve o interesse de verificar aquilo que ficava mais explícito no uso dos espaços, aquilo que os ambientes escolares possibilitavam e que fugia do padrão das escolas convencionais, como o uso do fogo de chão, a liberdade na configuração do mobiliário, o uso dos espaços construídos por eles, a presença dos pais e da comunidade em geral, a presença de animais na escola, a recepção de visitantes, entre outros elementos. Essa fluência que acontece no espaço escolar permite que os elementos que fazem parte do nhandereko estejam presentes, como despertar com o sol, tomar o mate e compartilhar o sonho, fumar o cachimbo, cultivar o milho, escutar os xeramõi, respeitar os nhe'ẽ (espíritos protetores) e se comunicar com eles por meio da fumaça sagrada. A escola também insere, nos processos pedagógicos, outros ambientes fundamentais para o nhanderekó: a mata e os seres que nela habitam; e a Opy como o lugar legítimo para a educação Guarani.

Identificamos que os Guarani estão constantemente reforçando seus vínculos territoriais na escola, por meio das construções (Opy Mirĩ e fogo coberto) e pelas pinturas murais, entre outros signos de ocupação. Dessa forma, a Escola Itaty vai se constituindo como um "lugar de identificação" (ZANIN, 2016), que pertence à comunidade, embora seja mantido e gerido com recursos públicos. É, ainda, um lugar de diálogo intercultural, em que apresentam aos não indígenas sua autoimagem, como uma forma de apresentarem seu ponto de vista, seu modo de vida, fortalecendo e compartilhando seus preceitos culturais.

A Escola Itaty transpõe os usos inicialmente determinados pela arquitetura e, dessa forma, expande os lugares de aprendizagem para outros ambientes da comunidade. Quando isso acontece, demonstra liberdade na apropriação e no uso dos espaços, expressando a conquista de inserir seus modos de aprendizagem, seu modo de vida e seu comportamento na configuração espacial da escola. A escola não somente possibilita o deslocamento, o ir e vir, ao respeitar e incentivar os percursos pelo território mais amplo, para outras aldeias, cidades, instituições parceiras, como também o movimento e a manifestação por seus direitos, sendo um lugar de aprender ferramentas de diálogo por meio da palavra e da ação. A escola também proporciona a continuidade do caminhar Guarani, relacionando a paisagem e seus elementos. Tudo isso ocorre em um aprendizado pelo corpo e por seus sentidos, o que se manifesta na escola e nos demais lugares de aprendizagem do território. E para além dele.

\section{AGRADECIMENTOS}

As autoras agradecem a colaboração de todas as pessoas que participaram da pesquisa, especialmente dos Guarani da Tekoa Itaty. 


\section{REFERÊNCIAS}

ALTINI, E. et al. (Org.). Por uma educação descolonial e libertadora: manifesto sobre a educação escolar indígena no Brasil. Brasília: CIMI, 2014. Disponível em:https://cimi.org.br/wp-content/uploads/2017/11/ Manifesto_EducacaoEscolarIndigena.pdf. Acesso em: 31 dez. 2014.

ANDRÉ, M. E. D. A. Etnografia da prática escolar. 18. ed. Campinas, SP: Papirus, 2012.

ANTUNES, E. Nhandereko nhanhembo'e nhembo' ea py. Sistema nacional de educação: um paradoxo do currículo diferenciado das escolas indígenas guarani da Grande Florianópolis. 2015. Trabalho de Conclusão de Curso (Graduação em Licenciatura Intercultural Indígena do Sul da Mata Atlântica)- Centro de Filosofia e Ciências Humanas, Universidade Federal de Santa Catarina, 2015.

ATTANÉ, A.; LANGEWIESCHE, K. Reflexões metodológicas sobre os usos da fotografia na antropologia. Cadernos de Antropologia e Imagem, Rio de Janeiro, v. 21, n. 2, p. 133-51, 2005.

BENITES, S. Nhe'ẽ, reko porã rã: nhemboea oexakarẽ. Fundamento da pessoa guarani, nosso bemestar futuro (educação tradicional): o olhar distorcido da escola. 2015. Trabalho de Conclusão de Curso (Graduação em Licenciatura Intercultural Indígena do Sul da Mata Atlântica) - Centro de Filosofia e Ciências Humanas, Universidade Federal de Santa Catarina, Florianópolis, 2015.

BERGAMASCHI, M. A. Indianizando a escola: movimentos de criação de práticas escolares diferenciadas nas aldeias Guarani e Kaingang. In: REUNIÃO DE ANTROPOLOGIA DO MERCOSUL, 7., 2007.Trabalho apresentado [...]. Porto Alegre: UFRGS, 2007.

BERGAMASCHI, M. A. Nhembo'e: enquanto o encanto permanece! Processos e práticas de escolarização nas aldeias Guarani. 2005. Tese (Doutorado em Educação) - Programa de Pós-Graduação em Educação, Universidade Federal do Rio Grande do Sul, Porto Alegre, 2005.

BONDÍA, J. L. Notas sobre a experiência e o saber de experiência. Revista Brasileira de Educação [on-line], Rio de Janeiro, n. 19, p. 20-8, jan./abr. 2002.

BORGES, L. C. Os Guarani Mbyá e a categoria tempo. Revista Tellus, Campo Grande, MS, ano 2, n. 2, p. 105-22, abr. 2002.

BRAND, A. J.; CALDERONI, V. A. M. O. Território e saberes tradicionais: articulações possíveis no espaço escolar indígena. Práxis Educativa (Brasil), Ponta Grossa, PR, v. 7, p. 133-53, dez. 2012. Disponível em: http://www.redalyc.org/articulo.oa?id=89425835007. Acesso em: 31 dez. 2014.

BRASIL. Ministério da Educação. Plano Nacional de Educação. Brasília: Inep, 2014.

BRASIL. Conselho Nacional de Educação, Câmara de Educação Básica. Resolução n. 5, de 22 de junho de 2012. Define Diretrizes Curriculares Nacionais para a Educação Escolar Indígena na Educação Básica. Disponível em: http://portal.mec.gov.br/index.php?option=com_docman\&view=download\&alias=11074rceb005-12-pdf\&category_slug=junho-2012-pdf\&Itemid=30192. Acesso em: 25 jun. 2020.

BRASIL. Ministério da Educação. Educação escolar indígena: diversidade sociocultural indígena ressignificando a escola. Brasília, DF, 2007. (Cadernos SECAD/MEC 3).

BRASIL. Conselho Nacional de Educação, Câmara de Educação Básica. Resolução n. 3, de 10 de novembro de 1999. Fixa as Diretrizes Nacionais para o funcionamento das escolas indígenas e dá outras providências. Disponível em: http://portal.mec.gov.br/cne/arquivos/pdf/CEB0399.pdf. Acesso em: 25 jun. 2020.

BRASIL. Constituição (1988). Constituição da República Federativa do Brasil. Brasília, DF: Centro Gráfico, 1988. 
CARVALHO, B. M. Intervenções habitacionais em comunidades tradicionais: uma solução ou um problema? In: ENCONTROS NACIONAIS DA ANPUR, 15., 2013. Anais[...].Disponível em: http://anais.anpur.org.br/ index.php/anaisenanpur/article/view/388. Acesso em: 25jun. 2020.

ELALI, G.A. Psicologia e Arquitetura: em busca do locus interdisciplinar. Estudos de Psicologia,Natal, RN, v. 2,n. 2, p. 349-62, jul./dez., 1997.

FARIA FILHO, L. M. O espaço escolar como objeto da história da educação: algumas reflexões. Revista da Faculdade de Educação/USP, São Paulo, v. 24, n. 1, p. 141-59, jan./jun. 1998. Disponível em: http://www. revistas.usp.br/rfe/article/download/59619/62716. Acesso em: 10 jan. 2017.

FERRARA, L. D. Leitura sem palavras. São Paulo: Ática, 1997.

FOUCAULT, M. Vigiar e punir: nascimento da prisão. Tradução Raquel Ramalhete. Petrópolis, RJ: Vozes, 1987.

FRAGO, A. V. Do espaço escolar e da escola como lugar: propostas e questões. In: FRAGO, A. V.; ESCOLANO, A. Currículo, espaço e subjetividade: a arquitetura como programa. Rio de Janeiro: DP\&A, 2001.

FUÃO, F. F. As formas do acolhimento na arquitetura. In: FUÃO, F. F.; SOLIS, D. E. (Org.).Derrida e a arquitetura. Rio de Janeiro: EdUERJ, 2014, p. 41-113.

GIFFORD, R. Environmental psychology: principles and practices. 2.ed.Boston: Allyn and Bacon, 1997.

GOERGEN, P. Espaço e tempo na escola: constatações e expectativas. In: FÓRUM PERMANENTE DE DESAFIOS DO MAGISTÉRIO, abr. 2005. Anais [...].Campinas, 2005.

GONDIM, S. M. G. Grupos focais como técnica de investigação qualitativa: desafios metodológicos. Paidéia, Ribeirão Preto, SP, v. 12, n. 24, p. 149-61, 2003.

GÜNTHER, H.; ELALI, G. A.; PINHEIRO, J. A abordagem multimétodos em Estudos Pessoa-Ambiente: características, definições e implicações. Brasília: LPA: Instituto de Psicologia: UNB, 2004. (Série: Textos de Psicologia Ambiental, n. 23).

INGOLD, T. Estar vivo: ensaios sobre movimento, conhecimento e descrição. Petrópolis, RJ: Vozes, 2015.

INGOLD, T. Da transmissão de representações à educação da atenção. Educação, Porto Alegre, v. 33, n. 1, p. 6-25, jan./abr. 2010.

INGOLD, T. The perception of the environment: essays on livelihood, dwelling and skill. London: Routledge, 2000.

KRINSKY, C. H. Contemporary Native American architecture: cultural regeneration and creativity. New York: Oxford University Press, 1996.

LÜDKE, M.; ANDRÉ, M. E. Pesquisa em educação: abordagens qualitativas. São Paulo: EPU, 2012.

MALNAR, J. M.; VODVARKA, F. New architecture on indigenous lands. Minneapolis: University of Minnesota, 2013

MBYÁ Guarani- Guerreiros da Liberdade. Documentário. Direção: Charles Cesconetto, 2004, 55 minutos.

MINAYO, M.C.S. Trabalho de campo: contexto de observação, interação e descoberta. In: MINAYO, M.C.S. (Org.); DESLANDES, S.F.; GOMES, R. Pesquisa social: teoria, método e criatividade. Petrópolis, RJ: Vozes, 2015. p. 61-78. (Coleção Temas Sociais). 
OLIVEIRA, R. C. O trabalho do antropólogo: olhar, ouvir, escrever. In: OLIVEIRA, R. C. O trabalho do antropólogo. Brasília:Paralelo Quinze; São Paulo: Editora da Unesp, 1998. p. 17-35.

POL, E. La apropiación del espacio. In: INIGUEZ, Lupicínio; POL, Enric (Org.). Cognición, representación y apropiación del espacio. Barcelona: Universitat Barcelona Publicacions, 1996. p. 45-60.

RAPOPORT, A. Cultura, arquitectura y diseño. Barcelona: Edicions UPC, 2003. (Coleção Arquitectonics. Mind, Land \& Society).

RAPOPORT, A. Development, culture change and supportive design. Habitat International,[S.I.], v. 7, n 5/6, p. 249-68, 1983.

RAPOPORT, A. Hechos y modelos. In: BROADBENT, G.Metodología del diseño arquitectónico. Barcelona: Editorial Gustavo Gili, 1971. p. 297-323.

RICHARDSON, R. J. Pesquisa social: métodos e técnicas. São Paulo: Atlas, 1985.

SÁ, C. Projetos arquitetônicos para comunidades indígenas. In: Vivienda rural y calidad de vida en los asentamientos rurales. Memoria del IV Seminario Iberoamericano. Red XIV- E. Puerto Montt, CH: CYTED/ HABYTED,2002.

SANTOS, S. C. Organização e atividades de assistência governamental aos índios. In: SANTOS, S. C. Educação e sociedades tribais. Porto Alegre: Movimento, 1975. p. 38-51.

SILVA, B. S. Arrematando o bordado, a escola indígena diferenciada. In: Seminário Infância Criança Indígena, 2., 2014. Anais [...]. São Carlos: Universidade Federal de São Carlos, 2014. Disponível em: https://infanciaindigena.files.wordpress.com/2014/10/arrematando-o-bordado-a-escola-indc3adgenadiferenciada-beatriz-sales-da-silva.pdf. Acesso em: 11 mar. 2015.

TASSINARI, A. M. I. A educação escolar indígena no contexto da antropologia brasileira. Ilha Revista de Antropologia, Florianópolis, v. 10, n. 1, p. 217-44, ago. 2008.

TASSINARI, A. M. I. Escola indígena: novos horizontes teóricos, novas fronteiras da educação. In: SILVA, A. L.; FERREIRA, M. K. L. (Org.). Antropologia, história e educação: a questão indígena e a escola. São Paulo: Global, 2001.

UNWIN, S. A análise da arquitetura. Tradução técnica Alexandre Salvaterra. 3. ed. Porto Alegre: Bookman, 2013.

ZANIN, N. Z. Intervenções arquitetônicas junto a povos indígenas: processo de projeto, apropriação e uso de ambientes escolares. 2018. Tese (Doutorado em Arquitetura e Urbanismo) - Universidade Federal de Santa Catarina, Florianópolis, SC, 2018.

ZANIN, N. Z. Dinâmicas culturais indígenas e suas relações com lugares de identificação. Cadernos NAUI, Florianópolis, v. 5, n. 8, p. 1-24, jan./jun. 2016.

ZANIN, N. Z. Abrigo na natureza: construção Mbyá-Guarani, sustentabilidade e intervenções externas. 2006. Dissertação (Mestrado em Engenharia) - Universidade Federal do Rio Grande do Sul, Porto Alegre, 2006. 


\section{Sobre as autoras:}

Nauíra Zanardo Zanin: Doutora em Arquitetura e Urbanismo pela Universidade Federal de Santa Catarina (UFSC). Mestre em Engenharia Civil pela Universidade Federal do Rio Grande do Sul (UFRGS), na linha de Edificações e Comunidades Sustentáveis. Arquiteta e urbanista pela mesma universidade. Professora adjunta do Curso de Arquitetura e Urbanismo da Universidade Federal da Fronteira Sul (UFFS), Campus Erechim, RS. Integrante do NAUI Dinâmicas Urbanas e Patrimônio Cultural (NAUI/UFSC) e pesquisadora do Instituto Nacional de Ciência e Tecnologia Brasil Plural (IBP). E-mail: nauira@nauira.arq.br, Orcid: https://orcid.org/0000-0001-8671-6445

Alicia Norma González de Castells: Pós-doutora pela Facultad de Filosofia y Letras da Universidade de Buenos Aires (UBA). Doutora interdisciplinar em Ciências Humanas e mestre em Antropologia pela Universidade Federal de Santa Catarina (UFSC). Graduada em Arquitetura e Urbanismo pela Universidade Nacional de La Plata, Argentina. Professora titular da UFSC. Professora dos Programas de Pós-Graduação em Antropologia Social e de Arquitetura e Urbanismo da UFSC. Coordenadora do NAUI Dinâmicas Urbanas e Patrimônio Cultural (www.naui.ufsc.br). Sócia da Associação Brasileira de Antropologia (ABA). Integrante do Comitê de Patrimônios e Museus da ABA. Pesquisadora do Instituto Brasil Plural (IBP).E-mail: alicianormacastells@gmail.com, Orcid: https://orcid.org/0000-0003-2545-7958 